\title{
DEPENDENCE OF THE RESULT ON THE EFFECTIVENESS OF PERFORMANCE IN THE WORLD WOMEN'S HANDBALL CHAMPIONSHIP 2016
}

\author{
Križan M., Mikulič M. \\ Sports Game Department, Faculty of Physical Education \\ and Sport, Comenius University, Slovakia
}

Corresponding author: Križan Martin, e-mail: martin.krizan@uniba.sk

Accepted for publication: June 9, 2018

Published: June 30, 2018

\section{DOI: 10.17309/tmfv.2018.2.02}

\begin{abstract}
The aim of the thesis was to analyze selected indicators of the game performance of the representative team in the defensive and offensive phases of the Slovak cadets' game, depending on the result of the match.

Materials and methods. In the thesis, we assumed that we would find a statistically significant relationship between the observed performance indicators and the result of the match. To obtain the research data, we used indirect observation of seven World Championship cadet matches of 2016. We used Hianik (2010) to diagnose game performance. We analyzed selected indicators of the game performance of the representative team of Slovak cadets $(n=18)$, depending on the result of the match.

Results. We found out that the result of the match is influenced by the game performance of the team in the defensive and offensive phases of the game. Furthermore, we have drawn the conclusion that the game result is also influenced by the performance of the goalkeeper $(\mathrm{p}<0.01)$.

Conclusions. The thesis highlighted the importance of the game performance of the team both in the defensive and the offensive phases of the game as well as the performance of the goalie in the match. The results obtained showed statistical significance $(p<0.01)$ and proved that the outcome of the match is influenced by the successful team play in attack and defense. Also, the result of the match depends on the goalkeeper's performance. We recommend using the computer program Hianik (2010) to evaluate the game performance of the team in the game.

Keywords: Team play, Goalkeeper performance, Match result, Cadets, Handball, Phases of the game.
\end{abstract}

\section{Introduction}

The result of a match is, in the same way as in all collective sports, a measure of the success or failure of a team. There are a number of factors affecting the end result of the match. Only a thorough analysis of the content of the game, or more precisely, the analysis of game performance gives us a perfect picture of all the determinants that affect the result of the match. This is true for all sports games, for football (Peráček et al., 2014, Holienka et al., 2014), basketball (Kucsa and Mačura, 2015), volleyball (Přidal and Zapletalová, 2010; Matúšov, 2013), hockey (Macoun, 2016). We classify the game performance of the team and the game performance of the individual as the most important factors. According to several authors (Táborský, 2009; Marczinka, 2010; Přidal, 2012; Hianik, 2016; Michalsik,

(c) Križan M., Mikulič M., 2018.
2014), game performance in handball is influenced by the factors of players' technical and tactical preparedness, conditional, biological, psychological and social factors. As stated by other authors (Wagner, Finkenzeller, Von Duvillard, 2014), the player's performance is influenced by three factors: individual readiness of each player, individual tactic maturity, and team interaction in the match. Another factor affecting gaming performance in handball is the various policy modifications. They played a significant role in the game itself, which accelerated and made it more attractive. The requirements for a player's fitness have increased in women's and men's handball equally (Michalsik, 2013). Bilge (2012) stated that the number of goals doubled after a change in rules. The performance of the goalkeeper and his/her success during the match is crucial.

The aim of our thesis was to find out whether the game performance of the team and the goalkeeper in 
the defensive and offensive phases of the game affects the final result of the match.

\section{Material \& methods}

The monitored set was made up of a representative team of Slovak cadets participating in the World Championship of 2016 in Slovakia. We evaluated the performance of our team in seven matches. Five matches in the base group, one round of 16 match and a match of 12th-13th place. Slovakia lost four matches and won three times. In the overall ranking of the 2016 World Cup they ranked 13th.

Research hypothesis

The aim of the thesis was to analyze selected indicators of the game performance of the representative team in the defensive and offensive phases of the Slovak cadets' game, depending on the result of the match.

Hypothesis: we expect the outcome of the match to be dependent on the observed performance factors of the team in the offensive and defensive phases of the game and the game performance of the goalie in the match.

\section{Research design}

We used ex post facto research. To obtain the research data, we used indirect observation of DVD recordings. To evaluate the performance in the offensive and defensive phases of the game, we used the Hianik rating methodology (2010). In the attack phase, we recorded 35 positive and 31 negative indicators, and in the defensive phase of the game -10 positive and 12 negative gaming performance indicators of the team. We observed 14 positive and 13 negative indicators of the goalkeeper's performance. To determine the dependence and relationship between the selected indicators and the result of the match, we used the statistical test of Chi-square independence. The results obtained were evaluated at $1 \%$ level of statistical significance.

\section{Results}

In the thesis, we examined the dependence of the outcome of the match on the monitored performance indicators of the team performance, or better said, the success of their implementation. In the offensive phase, the observed relation was statistically significant $(\mathrm{p}<0.01)$ (Table 1). In the winning matches, the set was higher in the number of positive and negative critical situations. The case was opposite for the played matches (Figure 1).

Similar results were gained when examining the success in the defensive phase of the game and the result of the match (Table 2). The tracked set in the winning games reached a higher $\%$ of the positive game situations, and in the lost matches the team reached a higher $\%$ of negative than positive gaming indicators (Figure 2).

Table 1. The relationship of the success of the attack phase to the result of the match

\begin{tabular}{llllllll}
\hline $\mathbf{X}^{2}$ & Positive & Negative & Total & $\%$ & Positive & Negative & Total \\
\hline Win & 2.66 & 3.55 & 6.21 & Win & $63.64 \%$ & $36.36 \%$ & 363 \\
Lose & 3.74 & 4.99 & 8.73 & Lose & $48.06 \%$ & $51.94 \%$ & 258 \\
Total & 6.4 & 8.54 & 14.94 & Total & 355 & 266 & 621 \\
\hline
\end{tabular}

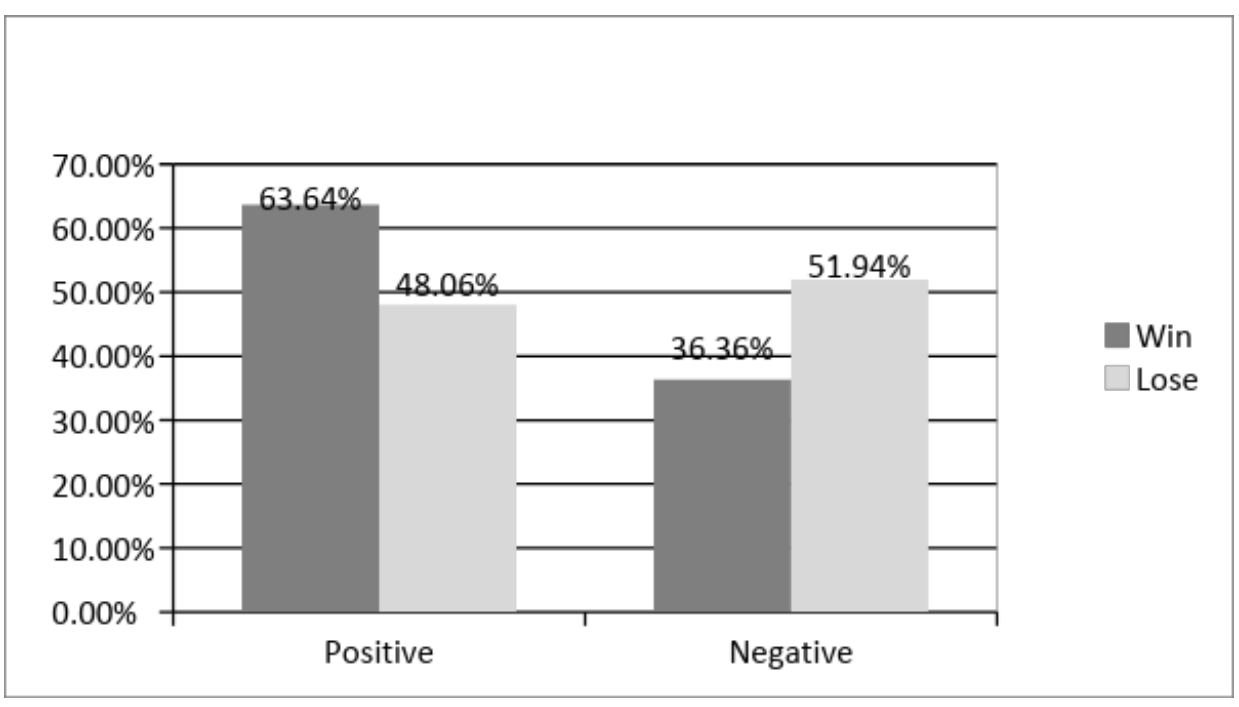

Figure 1. The relationship of the success in the attack phase to the result of the match 
Table 2. The relationship of the success in the defensive phase to the result of the match

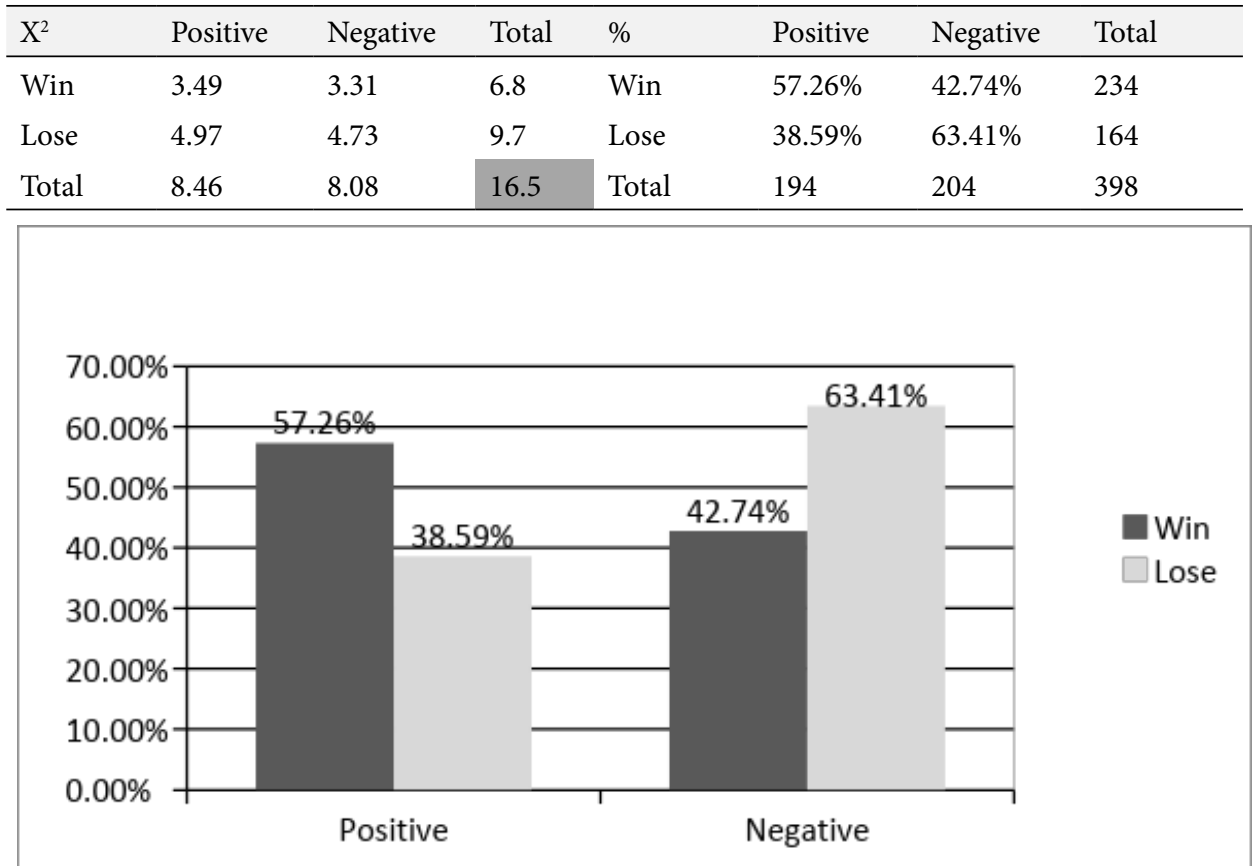

Figure 2. The relationship of the success in the defensive phase to the result of the match

Table 3. The relationship between the goalkeeper's performance and the result of the match

\begin{tabular}{llllllll}
\hline $\mathbf{X}^{2}$ & Positive & Negative & Total & $\%$ & Positive & Negative & Total \\
\hline Win & 2.03 & 1.33 & 3.36 & Win & $46.79 \%$ & $53.21 \%$ & 156 \\
Lose & 2.09 & 1.37 & 3.46 & Lose & $32.24 \%$ & $67.76 \%$ & 152 \\
Total & 4.12 & 2.7 & 6.82 & Total & 122 & 186 & 308 \\
\hline
\end{tabular}

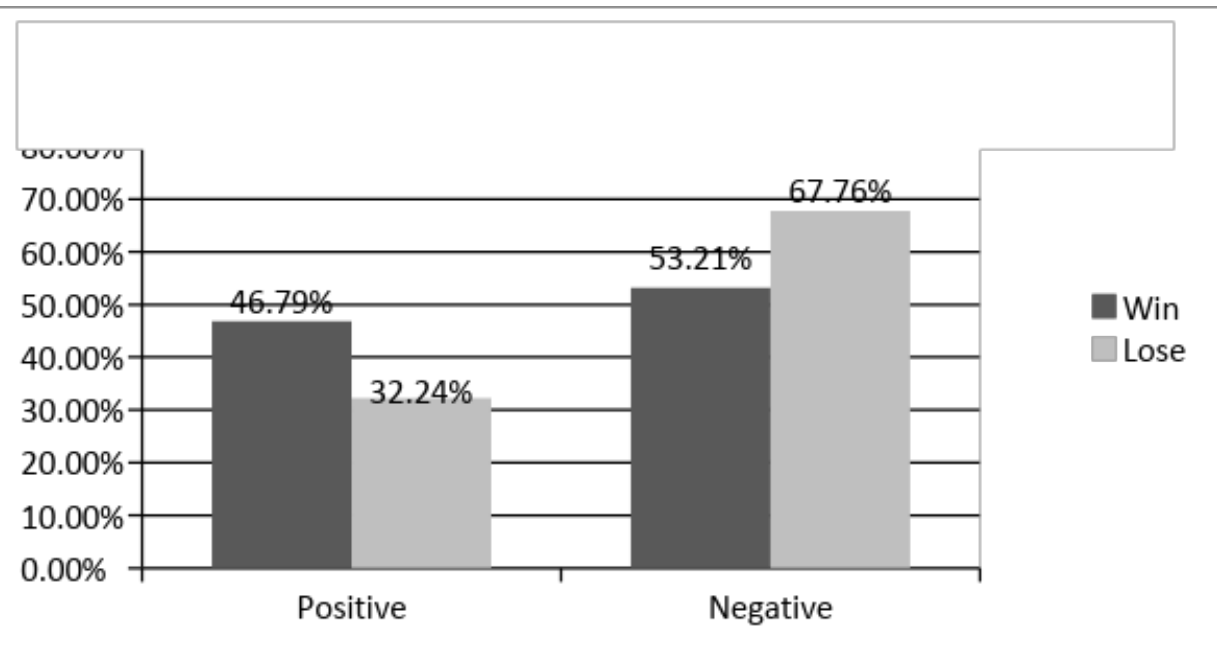

Figure 3. The relationship between the goalkeeper's performance and the result of the match

When examining how the goalkeeper's performance affects the result of the match, we have reached the following results. The goalkeeper's performance significantly affects $(\mathrm{p}<0.01)$ the match result (Table 3$)$. Despite the fact that both in the winning and the lost matches, the goalkeepers have faced more negative than positive gaming situations (Figure 3), it is important to note that the game performance of the goalie in the match and the success of catching warts from different positions, or better said, her interventions ranged from 
$33 \%$ to $39 \%$ at the top events of the World and European Women's Handball Championships (Kovacs 2018).

\section{Discussion}

In the thesis, we dealt with the game play of the team in the defensive and offensive phases of the match and the performance of the goalkeeper based on the evaluation of critical game situations in the match. From the results obtained, we determined the dependence of the success of these game performance indicators on the result of the match. We found that the success of the observed performance gaming indicators in each stage of the match, as well as the performance of the goalkeeper have a statistically significant $(\mathrm{p}<0.01)$ effect on the result of the match. In the offensive phase of the game, we recorded 621 critical situations, out of which the tracked team realized 363 successful or positive critical situations and 258 unsuccessful critical situations. In the winning games, the tracked team reached $15 \%$ more positive than negative game situations. On the other hand, we have seen $15 \%$ more negative than positive game situations in the lost matches. In the defensive phase of the game, we recorded 398 critical game situations, 234 positive and 164 negative. Similarly to the offensive phase of the game, in the defensive part, the team of Slovakia achieved a higher number, $19 \%$ more positive game situations than negative. On the other hand, there were up to $21 \%$ of negative gaming situations in the lost games. When we examined the dependence of the goalie's performance on the outcome of the match, we recorded a total of 308 critical gaming situations and the balance was achieved. The goalkeepers recorded 156 positive or 152 negative game situations. Straková (2016) was also examining the success of the game performance and its effect on the result of the match. She also observed the dependency of game performance in the defensive and offensive phases of the game and the performance of the goalkeeper and its effect on the result of the match. Straková recorded statistical significance at $1 \%$ level $(\mathrm{p}<0.01)$ only in terms of the dependence of the outcome of the match on the defensive phase of the game. Basilio Pueo, Jose J. Espina (2017) determined the dependency of the number of excluded players in the match against the result of the match at the top events of the World and European Championships and the Olympic Games in 1984-2014. However, the game in unequal conditions of the players on the field does not significantly affect the outcome of the match. Gaming performance indicators that could influence the result of the match were being identified by Daza, Andrés and Tango (2017). They analyzed 80 World Men's Handball Championship matches in 2015 in Qatar. They found that the outcome of the match statistically significantly $(\mathrm{p}<0.05)$ depends on a combination of multiple performance gaming indicators in the defensive and offensive phases of the game, such as the success of shots rate, the number of technical errors, and also the success of the goalkeeper's catches.

\section{Conclusions}

The thesis highlighted the importance of the game performance of the team both in the defensive and the offensive phases of the game as well as the performance of the goalie in the match. The results obtained showed statistical significance $(\mathrm{p}<0.01)$ and proved that the outcome of the match is influenced by the successful team play in attack and defense. Also the result of the match depends on the goalkeeper's performance. We recommend using the computer program Hianik (2010) to evaluate the game performance of the team in the game.

\section{References}

Bilge, M. (2012). Game Analysis of Olympic, World and European Championships in Men's Handball. Journal of Human Kinetics, 35, 109-118.

Daza, G., Andrés, A., \& Tarrago, R. (2017). Match Statistics as Predictors of Team's Performance in Elite competitive Handball. [online]. [citované 1.5.2017]. dostupné z: http://www.cafyd.com/REVISTA/ojs/index. php/ricyde/article/view/1144

Hianik, J. (2010). Vztah ukazovatelov herného výkonu družstva $\mathrm{k}$ výsledku zápasu v hádzanej. Bratislava: Peter Mačura -PEEM, s. 10, 46, ISBN 978-80-8113-019-9.

Hianik, J. (2016). Vztah ukazovatelov herného výkonu družstva žien $\mathrm{k}$ výsledku zápasu v hádzanej. Nitra: Univerzita Konštantína Filozofa, ISBN 978-80-5581058-4.

Holienka, M. et al. (2015) Analýza herného výkonu a finálnych herných činností vybraných družstiev a hráčov na MS 2014 vo futbale.

Kovacs, P. (2018) Comparison of the Men's and womann's EURO 2016, EHF 2018 Renewal Seminar in Porec. [online]. [citované 10.4.2017]. dostupné $\mathrm{z}$ : http:// activities.eurohandball.com/ehfcan/23507

Kucsa, R. \& Mačura, P. (2015) Physical characteristics of female basketball players according to playing position In: Acta Facultatis Educationis Physicae Universitatis Comenianae, 55/I, MAY 2015. - ISSN 0520-7371. s. 49-56.

Marczinka, Z. (2010). Coaching Young Handball Players [online]. [citované 10.4.2017]. dostupné z: http:// home.eurohandball.com/ehf_files/Publikation/WP Coaching\%20Young\%20Handball\%20Players.pdf

Michalsik, L.B., Madsen, K., \& Aagaard, P. (2014). Match Performance and Physiological Capacity of Female Elite Team Handball Players. Int J Sports Med 35(7): 595-607.

Michalsik, L.B., Madsen, K., \& Aagaard, P. (2013). Locomotion Characteristics and Match Induced 
Impairments in Physical Performance in Male Elite Team Handball Players. Int J Sports Med 34(7): 590599.

Macoun, L. (2016) Hodnotenie herného výkonu v ladovom hokeji pomocou video analýzy. Bratislava, 2016 DP.

Přidal, V. (2012) Herný výkon v športových hrách. Bratislava: IMC AGENCY, ISBN 978-80-89257-49-2.

Přidal, V., \& Zapletalová, L. (2010) Volejbal herný výkon tréning - riadenie. Bratislava: Peter Mačura - PEEM, 2010 ISBN 978-80-8113-030-4.

Pueo, B., \& Espina-Agullo, J. (2017) Relationship between exclusions and final results in European Championships, World Championships and Olympic Games in men's handball 1982-2014. Journal of Physical Education and Sport, 17(3), Art 178, pp.1158 -1162 .

Straková, M. (2016). Kvalitatívne a kvantitatívne ukazovatele herného výkonu vo vztahu k výsledku zápasu v hádzanej. Bratislava: Diplomová práca. Univerzita Komenského v Bratislave, Fakulta telesnej výchovy a športu, Katedra športových hier.

Táborský, F. (2009). Metodologická východiska pozorování a hodnocení herního výkonu. In: V. Suss, J. Buchtel a kol. Hodnocení herního výkonu ve sportových hrách. Praha: Nakladatelství Karolinum, ISBN 978-80-2461680-3.

Matúšov, M. (2013) Vztah medzi výškou dosahu a výškou zásahu lopty pri smeči v rôznych vekových kategóriách volejbalistiek. In: Acta Facultatis Educationis Physicae Universitatis Comenianae, 53/II, 2013. - ISBN 978-80223-3510-2. S. 23-32

Wagner, H., Finkenzeller, T., Wuethr, S., \& von Duvillard, S. P. (2014). Individual and team performance in team-handball: A Review. Journal of Sports Science \& Medicine, 13(4), 808-816.

\title{
ВПЛИВ ЕФЕКТИВНОСТІ ГРИ НА РЕЗУЛЬТАТ НА ЧЕМПІОНАТІ СВІТУ 3 ГАНДБОЛУ СЕРЕД ЖІНОК 2016 РОКУ
}

\author{
Крижан М., Мікуліч М. \\ Кафедра спортивних ігор, факультет фізичного виховання \\ та спорту, університет імені Коменського, Словаччина \\ Реферат. Стаття: 6 с., 3 табл., 3 рис., 18 джерел.
}

Метою даної статті $€$ аналіз окремих показників ефективності гри збірної команди словацьких кадетів під час оборонної та наступальної фаз залежно від результату матчу.

Матеріали та методи: у статті було зроблено припущення щодо існування статистично значущого зв'язку між спостережуваними показниками ефективності та результатом матчу. Для отримання дослідницьких даних було застосовано непряме спостереження семи кадетських матчів Чемпіонату світу 2016 року. Для діагностики показників гри використано програму Hianik (2010). Проаналізовано окремі показники ефективності гри збірної команди словацьких кадетів $(\mathrm{n}=18)$ залежно від результату матчу.

Результати: виявлено, що на результат матчу впливає ефективність гри команди під час оборон- ної та наступальної фаз матчу. Крім того зроблено висновок, що результат матчу також залежить від ефективності гри воротаря $(\mathrm{p}<0,01)$.

Висновки: у роботі висвітлено важливість ефективності гри команди як під час оборонної, так і наступальної фаз матчу, а також гри воротаря. Отримані результати свідчать, що на статистичну значущість $(\mathrm{p}<0,01)$ та результат матчу впливає успішна командна гра під час атаки та оборони. Також результат матчу залежить від ефективності гри воротаря. Рекомендовано використовувати комп'ютерну програму Hianik (2010) для оцінки ефективності гри команди у матчі.

Ключові слова: командна гра, ефективність гри воротаря, результат матчу, кадети, гандбол, фази матчу. 


\title{
ВЛИЯНИЕ ЭФФЕКТИВНОСТИ ИГРЫ НА РЕЗУЛЬТАТ НА ЧЕМПИОНАТЕ МИРА ПО ГАНДБОЛУ СРЕДИ ЖЕНЩИН 2016
}

\author{
Крижан М., Микулич М. \\ Кафедра спортивных игр, факультет физического воспитания \\ и спорта, университет имени Коменского, Словакия \\ Реферат. Статья: 6с., 3 табл., 3 рис., 18 источников.
}

Целью данной статьи является анализ отдельных показателей эффективности игры сборной команды словацких кадетов во время военной и наступательной фаз в зависимости от результата матча.

Материалы и методы: в статье было сделано предположение о существовании статистически значимой связи между наблюдаемыми показателями эффективности и результатом матча. Для получения исследовательских данных были применены косвенное наблюдение семи кадетских матчей Чемпионата мира 2016 года. Для диагностики показателей игры с помощью программы Hianik (2010). Проанализированы отдельные показатели эффективности игры сборной команды словацких кадетов $(\mathrm{n}=18)$ в зависимости от результата матча.

Результаты: выявлено, что на результат матча влияет эффективность игры команды во время оборонительной и наступательной фаз матча. Кроме того сделан вывод, что результат матча также зависит от эффективности игры вратаря $(\mathrm{p}<0,01)$.

Выводы: в работе освещены важность эффективности игры команды как во время оборонительной, так и наступательной фаз матча, а также игры вратаря. Полученные результаты свидетельствуют, что на статистическую значимость $(\mathrm{p}<0,01)$ и результат матча влияет успешная командная игра в атаке и обороне. Также результат матча зависит от эффективности игры вратаря. Рекомендуется использовать компьютерную программу Hianik (2010) для оценки эффективности игры команды в матче.

Ключевые слова: командная игра, эффективность игры вратаря, результат матча, кадеты, гандбол, фазы матча.

\section{Information about the authors:}

\section{Križan Martin}

https://orcid.org/0000-0001-5464-6673

Sports Game Department, Faculty of Physical Education and Sport, Comenius University, SLOVAKIA

\section{Mikulič Martin}

https://orcid.org/0000-0001-5729-6242

Sports Game Department, Faculty of Physical Education and Sport, Comenius University, SLOVAKIA
Cite this article as: Križan Martin, \& Mikulič Martin (2018). Dependence of the Result on the Effectiveness of Performance in the World Women's Handball Championship 2016. Teorìa ta Metodika Fìzičnogo Vihovannâ [Theory and Methods of the Physical Education], 18(2), 63-68. https://doi.org/10.17309/tmfv.2018.2.02

Received: 14.04 .2018

Accepted: 09.06.2018; Published: 30.06.2018 